\section{Interessant, men variabelt om samarbeidets anatomi og fysiologi}

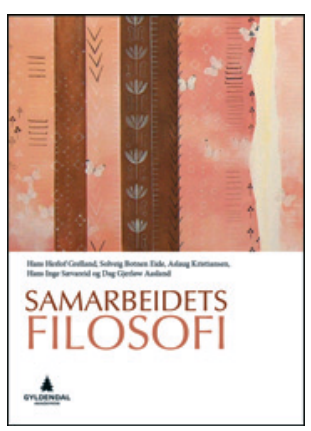

\author{
Hans Herlof Grelland, Solveig Botnen Eide, \\ Aslaug Kristiansen et al. \\ Samarbeidets filosofi \\ 210 s, ill. Oslo: Gyldendal Akademisk, 2014 \\ Pris NOK 345 \\ ISBN 978-82-05-46121-5
}

Samarbeidets filosofi er skrevet av fem forfattere med ulik fagbakgrunn, alle med tilknytning til Universitetet i Agder. De har ikke oppgitt noen spesiell målgruppe.

Boken inneholder ni kapitler, en innledning og et etterord. Kapitlene bærer preg av at de ikke har samme forfatter. Både form og språk varierer i ganske stor grad. Enkelte kapitler kan virke vanskeligere tilgjengelig enn andre.

I etterordet skriver forfatterne at et gjennomgående tema for boken er samarbeidets mulighetsrom. Det er et rom som skapes underveis i samarbeidsprosessen, og som ikke er kjent i forkant. $\AA$ utvide dette rommet krever at deltakerne er åpne for det som er annerledes og ukjent, og som derfor kan tilføre nye perspektiver og erfaringer. For å finne ut hva som skal til for å lykkes med en slik prosess, går de blant annet inn på følgende temaer:

- hva er samarbeid?

- tillit

- kommunikasjon og følelser

- ulikhet og likeverd

- hvordan forholde seg til andre?

- å samarbeide med seg selv

- ulike måter å stille spørsmål på

- årsaker til at samarbeid blir vellykket eller skranter

For å belyse dette drøfter de tekster av filosofer som blant andre Hans Skjervheim, Alan Badiou, Emmanuel Levinas, Martin Buber, Aaron Antonovsky og Hanna Arendt, kombinert med egne refleksjoner. De bruker også praktiske eksempler. Dette fungerer stort sett bra, men ikke alle eksemplene er like gode. For eksempel forklares helsevesenets gode jobb under 22. juli-tragedien med at det som var av struktur og retningslinjer, ikke ble fulgt. Altså at det beste er å ikke ha noen planer eller retningslinjer for slike hendelser. Det faller på sin egen urimelighet.

Én av forfatterne faller også for fristelsen til å gi New Public Management skylden for alt som er trist og leit i helsevesenet også skrantende samarbeid. Det gjør han uten å definere nærmere hva han legger i begrepet. Dermed blir det vanskelig å få tak i hans forklaring på hvorfor det skranter.

Dette er eksempler som skjemmer en ellers interessant og tankevekkende gjennomgang av mange fasetter ved menneskelig samarbeid. For mange som arbeider med og interesserer seg for samarbeid, vil noe av stoffet være kjent. Likevel blir det her presentert på en litt ny måte. Noe stoff er nytt, i hvert fall for undertegnede.

Boken vil bidra med nyttig innsikt til alle som befinner seg i en situasjon der de må samarbeide med andre mennesker, det være seg på jobben eller $\mathrm{i}$ andre sammenhenger.

\section{Viktig bok om mestring av alvorlige psykiske lidelser}

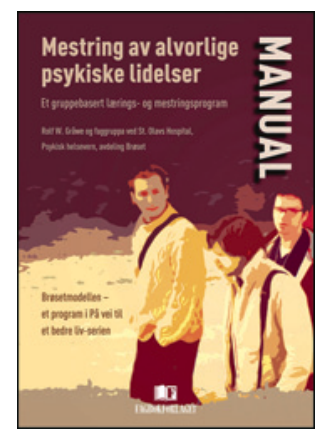

Rolf W. Gråwe og faggruppa ved St. Olavs Hospital, Psykisk helsevern, avdeling Brøset Mestring av alvorlige psykiske lidelser Et gruppebasert lærings-og mestringsprogram. Manual. 151 s, ill. Bergen: Fagbokforlaget, 2014. Pris NOK 319 ISBN 978-82-321-0359-1

Denne lille boken (som er en del av «På vei til et bedre liv»-serien) er viktig for alle som arbeider i psykisk helsevern, ikke bare for dem som driver eller har tenkt å drive lærings- og mestringsprogrammer. Det er en manual for et strukturert program som integrerer sammensatte tiltak for pasienter med alvorlige, komplekse lidelser, og inneholder for eksempel tiltak rettet mot rusmiddelproblemer, aggresjon og utagering, fritid og venner, psykoedukasjon med hensyn til medisiner o.a. Slike programmer er en helt nødvendig del av de samlede behandlingstiltakene rettet mot pasienter i målgruppen. Hvis jeg savner noe, vil det være en litt bedre beskrivelse av hvilke pasienter som inkluderes i programmet, om det er noen eksklusjonskriterier, og noen mer spesifikke tiltak rettet mot stemmehøring.

Boken er lettlest, pedagogisk og oversiktlig, og den beskriver grundig hvordan et slikt program bør drives. Under lesingen kom det tydelig frem at dette er et program som er gjennomtenkt og har bevist sin berettigelse gjennom praksis. Instruksjonene til kurslederne er gode, gir gjennomtenkt henvisning til aktuell kunnskap, og sammenhengen med pasientenes hjemmearbeid og arbeidsbok virker funksjonell. Spesielt vil jeg fremheve at rusmodulen er bra og oppdatert. Det foreligger forskning både fra Norge og USA som beskriver resultatene, referansene finnes i manualen.

Det var en fornøyelse å lese en så gjennomarbeidet manual. Jeg tenker at alle som arbeider i psykisk helsevern, bør lese denne boken - ikke for at de skal drive slike kurs, men for å få med seg hva et slikt program inneholder, den tenkningen som ligger bak programmet, og den holdningen til pasientene som gjennomsyrer fremstillingen. Vi vet at alt som mobiliserer pasientenes egenmestring, har en avgjørende, positiv betydning for resultatet av behandlingen og for pasientenes livskvalitet i fremtiden, og et slikt program er nok den beste måten vi i dag kan få til det på. Jeg tenker også at det er godt mulig at den individuelle planen blir langt bedre og mer funksjonell for de pasientene som går gjennom programmet.

Alt $\mathrm{i}$ alt en bok som er moderne, oppdatert og godt skrevet, og som anbefales varmt.

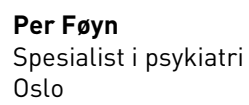

